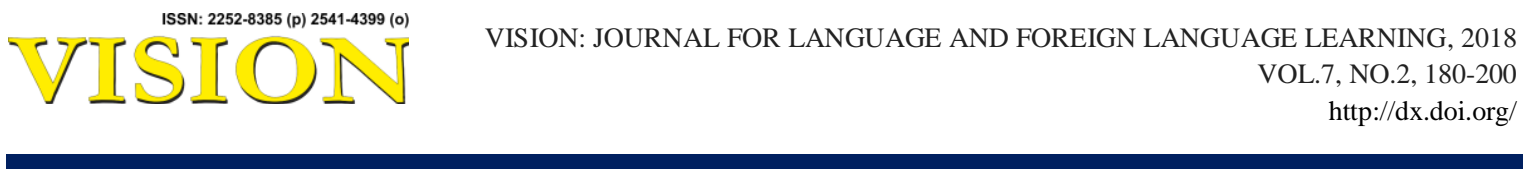

\title{
The Effect of Task-Based Language Teaching On the Teaching Practice of Pre Service English Teacher
}

\author{
Nadiah Ma'mun \\ UIN Walisongo Semarang \\ nadiah_makmun@walisongo.ac.id
}

\begin{abstract}
This present study investigated the effect of Task-Based Language Teaching (TBLT) on the teaching practice of pre-service English teacher. The research method used to study was experimental research with one group design. The sample of the research was 25 students of Microteaching class at English Education Department. The data were collected through the Performance Test of teaching practice as the instrument of the research. After conducting the pre-test of the Performance test of teaching practice and giving the treatment by using TBLT and the post-test. The result of post-test is higher than pre-test. It happened after the researcher gave treatments using TBLT to the pre-service English teacher. The researcher used the t-test formula to discover the significant difference between the teaching practice of the pre-service English teacher and the use of TBLT. The score of t-test was 8.90 , higher than t-table. Thus, it could be concluded that there was a significant difference before and after being taught by using TBLT. The result showed that it had a positive effect.
\end{abstract}

\section{ARTICLE HISTORY}

Received 27 November 2018 Accepted 10 December 2018

\section{KEYWORDS}

Task-based language teaching; pre-service English teacher and teaching practice

\section{INTRODUCTION}

A Professional teacher should consider suitable strategies for teaching English (Volya, 2009). As focus of teaching strategies in applying TBLT by giving the students some task is to improve the oral production of the students and their communicative competence in a real situation, it requires the teacher not only to create a warm and humanistic classroom atmosphere, but also to provide each student with a turn to speak or a role to play. The students as a candidate of a professional teacher who takes Microteaching must prepare themselves to know teaching strategies well, in order that they will not find difficulty in doing teaching practice (teaching internship/PPL) and they will be self-confident. They must not only master the knowledge of teaching strategies in applying TBLT but also can apply the teaching strategy from the beginning until the end of the class.

The students also must master the speaking skill fluency and accuracy, in order that they can explain the material communicatively. The students can also increase the knowledge and the experience especially in explaining the material of English classroom from the beginning until the end of the class. Also, English 
lecturer had better prepare their students to be competent in teaching strategy and speaking skill of English classroom. The students need more time to apply the teaching strategy when they want to reach a professional teacher.

Micro-Teaching is one of the subjects that must be given to students all faculties of education and the prerequisite courses before they are deployed in school to achieve PPL or teaching internship. Microteaching is an activity that very important for any student or pre-service English teacher. The purpose of microteaching for all of the students in faculties of education is to fulfill the demands that putting oneself fully and professionally in the field of teacher training. The aims of learning micro teaching generally are to train and prepare the students as prospective teachers in facing the job of teaching-learning entirely at class by having a knowledge, skill, proficiency, and attitude as a professional teacher. To train students to become the future teacher who professional certainly is not easy, micro teaching is learning the process of implementation that should proceed effectively. Moreover, Microteaching is very important, how the implementation of microteaching for the readiness of a professional pre-service English teacher is needed to invent a further study, so that all the problems and the imperfections on implementation can be beneficial to improve the quality of microteaching in the future to be the readiness of professional pre-service English teacher.

The pre-service English teachers believed that micro-teaching practice played a crucial role in shaping their teaching methodology and gave them a great chance to transfer the theoretical information they learned into the practice. The interview results revealed that microteaching practices had a positive effect on their teaching regarding material preparation and adaptation, various activities, peer interaction and a sense of readiness (İsmail, 2011). Microteaching is a remarkable factor used in teaching practices of pre-service teachers (Gorgen, 2003, as cited in Saban, 2013, p.234). Microteaching is one of the efforts by the pre-service teachers to transfer the knowledge and skills into action, and thus, they try to bridge the gap between the theory and practice (Gurser, Bayrak, Yalcin, Acikyildiz \& Dogler, 2005, as cited in Saban, 2013, p.234).

For most EFL student teachers, teaching practice in the microteaching course is their first experience of teaching. Even though they have acquired theoretical courses such as the method of language teaching, second language acquisition, language assessment, speaking skills and so forth, they still encounter problems during their teaching practice. The problems vary from how to design the lesson plan, how to implement the plan into meaningful activities, until how to reflect on their teaching. As the teaching practice is conducted individually, the student teachers might not always be able to identify their problems as well as to cope with them. Microteaching offers the collaborative microteaching that brings about the benefits of teaching strategies, speaking skills and enables the student teachers to perform better in their teaching practice (Suryani, 2015). 
There are many strategies that can be applied by the teacher to maximize their role in the classroom, but most of them did not try to find a variety of method and anyways to be more attractive. Here is how a teacher is the students as learned cantered especially involved them in many activities. It is necessary by the teacher to stimulate students in order to attitude in learning English. In term of teaching strategy, there are many strategies that can be applied for improving students' achievement in EFL. One of the methods is Task-Based Language Teaching. TaskBased Language Teaching (TBLT) has been developed during the last twenty years. Its character as a learner-center approach makes it becomes a highly recommended approach to be used by EFL teachers. Task-Based Language Teaching itself is an approach which emphasizes the process of learning to communicate through interaction in the target language (Nunan, 2004).

This study presented many features of TBLT, which will encourage preservice English teachers to implement it in the classroom: TBLT improves the learning of communicative skills better than the conventional way of teaching. Unlike traditional teacher-centered classroom where the teacher is the dominant figure, in task-based learning the learners are at the center of the learning process: they are expected to assume a high degree of responsibility for their own learning through effective self-learning, working with others, and demonstrating an ability of their learning achievements, TBLT promotes the actual use of target learning, TBLT enhances collaboration and self-learning, TBLT merge between fun and learning, which stimulate intrinsic motivation. In other words, TBLT is enjoyable and motivating (Nunan, 2002:13).

Few studies (Kafipour, Jafari and Khojasyeh, 2018) were found in the field of TBLT. This study aims at investigating the effect of Task-Based Instruction (TBI) on the development of Grammar proficiency of elementary EFL Learners and their motivation after implementing TBI.

\section{METHOD}

In this research, the researcher used the quantitative method in the form of experimental research. The type of pre-experimental used here was one-group pretestposttest design (Sugiyono, 2016: 107). The aim of the researcher conducting this research is to examine the significant difference in applying teaching strategy of TBLT on teaching practice of pre-service English teacher. There are two variables used in this study. The variables are; (1) Dependent variable or $\mathrm{Y}$ variable is teaching practice, and (2) Independent variables are using TBLT (X).

The population of this study was the seven semester of English Education department students in UIN Walisongo Semarang. There were three classes; PBI 7A, PBI 7B, and PBI 7C. The researcher took PBI 7C as the sample of the study with several considerations. First, after the researcher conducted a survey on June, then the result of Microteaching course was most of PBI 7C students got 65-74 score. It 
can be concluded that the ability of their teaching practice was still under the standard. Second, they still need much more guidance in applying teaching strategies in their teaching practice. Moreover, the third, they were lack of self-confident and not ready to do teaching practice in some schools. The technique used by the research in taking sample was purposive sampling (Sugiyono, 2016: 123). There are 25 students.

In this study, the researcher used pre-test and post-test as the data collection technique. A pre-test in the form of the performance of the Micro-Teaching is used to know their teaching practice before giving a treatment by using TBLT. The researcher noticed their performance, in applying some strategies. Then post-test was used to measuring the students' improvement. The data that had already gotten from the first phase (pretest) until the last phase (post-test) were compiled by the researcher. Then the researcher analyzed the effectiveness of using TBLT of preservice English teacher on their teaching practice by using the formula of t-test (Sugiyono, 2011).

The steps of analyzing the data specifically are as follows:

a. Scoring of pretest before using TBLT.

b. Scoring of post-test after using TBLT.

c. To find out the significant difference between the English Education Department students of UIN Walisongo Semarang in the academic year 2015/2016 before and after being taught by using TBLT, the researcher counted Mean $X=\frac{\sum f x}{N}$ and deviation standard. Deviation Standard

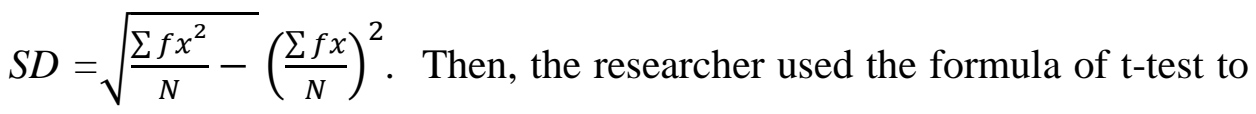
investigate the significant difference between the result before and after using TBLT as following $\mathrm{t}_{0} \quad=\frac{M_{x}-M_{y}}{S E_{M x-M y}}$.

\section{FINDING AND DISCUSSION}

1. The Teaching Practice of the Pre-service English teacher in the academic year 2015/2016 before being taught by using Task-Based Language Teaching

In finding the significant difference of using TBLT, the researcher conducted a pre-test to the students in order to know the teaching practice of pre-service English teacher. The performance Test of teaching practice was provided by the researcher that would be used as the pre-test and those all rubrics have been checked the validity and the reliability to the experts. 
Table 1

The rubric of teaching performance for Pre Test and Post Test

\begin{tabular}{|c|c|c|c|c|c|c|}
\hline Aspect & Indicator & 1 & 2 & 3 & 4 & 5 \\
\hline \multirow{9}{*}{ 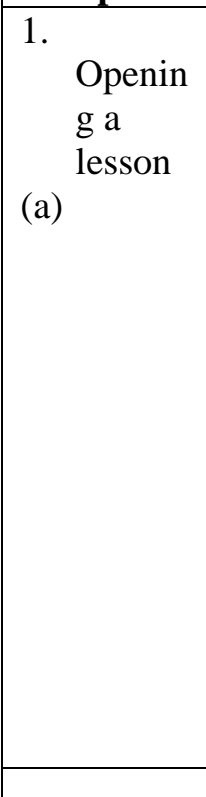 } & $\begin{array}{l}\text { 1. Teacher motivates and makes students } \\
\text { ready to learn }\end{array}$ & & & & & \\
\hline & $\begin{array}{l}\text { 2. The teacher explains the learning } \\
\text { goals }\end{array}$ & & & & & \\
\hline & $\begin{array}{l}\text { 3. Teachers explain how the presented } \\
\text { material is related to the previous one }\end{array}$ & & & & & \\
\hline & $\begin{array}{l}\text { 4. Teacher informs the coverage of the } \\
\text { materials }\end{array}$ & & & & & \\
\hline & $\begin{array}{l}\text { 5. The teacher explains the techniques } \\
\text { and the stages of learning }\end{array}$ & & & & & \\
\hline & $\begin{array}{l}\text { 6. Teacher informs the scope of the } \\
\text { assessment }\end{array}$ & & & & & \\
\hline & $\begin{array}{l}\text { 7. Teacher informs the technique of } \\
\text { assessment }\end{array}$ & & & & & \\
\hline & $\begin{array}{l}\text { 8. Teacher gets information about the } \\
\text { level of students' understanding of the } \\
\text { lesson }\end{array}$ & & & & & \\
\hline & 8 items & & & & & \\
\hline \multirow{14}{*}{$\begin{array}{l}2 . \\
\text { Organizi } \\
\text { ng the } \\
\text { activities } \\
\text { (various } \\
\text { tasks) in } \\
\text { ELT } \\
\text { (b) }\end{array}$} & $\begin{array}{l}\text { Activities are systematically } \\
\text { implemented and facilitate the } \\
\text { achievement of learning goals }\end{array}$ & & & & & \\
\hline & 2. Activities are learner-centered (SCL) & & & & & \\
\hline & $\begin{array}{l}\text { 3. Activities facilitate the learning of } \\
\text { knowledge }\end{array}$ & & & & & \\
\hline & $\begin{array}{l}\text { 4. Activities facilitate the learning of the } \\
\text { skill }\end{array}$ & & & & & \\
\hline & $\begin{array}{l}\text { 5. The activities develop students' } \\
\text { collaboration skill }\end{array}$ & & & & & \\
\hline & $\begin{array}{l}\text { 6. The activities develop students' } \\
\text { critical thinking skill }\end{array}$ & & & & & \\
\hline & $\begin{array}{l}\text { 7. The activities develop students' } \\
\text { creativity }\end{array}$ & & & & & \\
\hline & $\begin{array}{l}\text { 8. The activities develop students' } \\
\text { spiritual attitude }\end{array}$ & & & & & \\
\hline & $\begin{array}{l}\text { 9. The activities develop students' social } \\
\text { attitude }\end{array}$ & & & & & \\
\hline & $\begin{array}{l}\text { 10. Teacher uses concrete examples and } \\
\text { illustration }\end{array}$ & & & & & \\
\hline & 11. Teacher models good behavior & & & & & \\
\hline & $\begin{array}{l}\text { 12. Teacher implements varied kinds of } \\
\text { activities and/or interaction patterns }\end{array}$ & & & & & \\
\hline & 13. The teacher plays a variety of roles & & & & & \\
\hline & 13 items & & & & & \\
\hline \multirow[t]{2}{*}{$\begin{array}{l}\text { 3. Using } \\
\text { media (c) }\end{array}$} & $\begin{array}{l}\text { 1. The teacher uses varied kinds of media } \\
\text { appropriately }\end{array}$ & & & & & \\
\hline & 2. Teacher implemented the media & & & & & \\
\hline
\end{tabular}




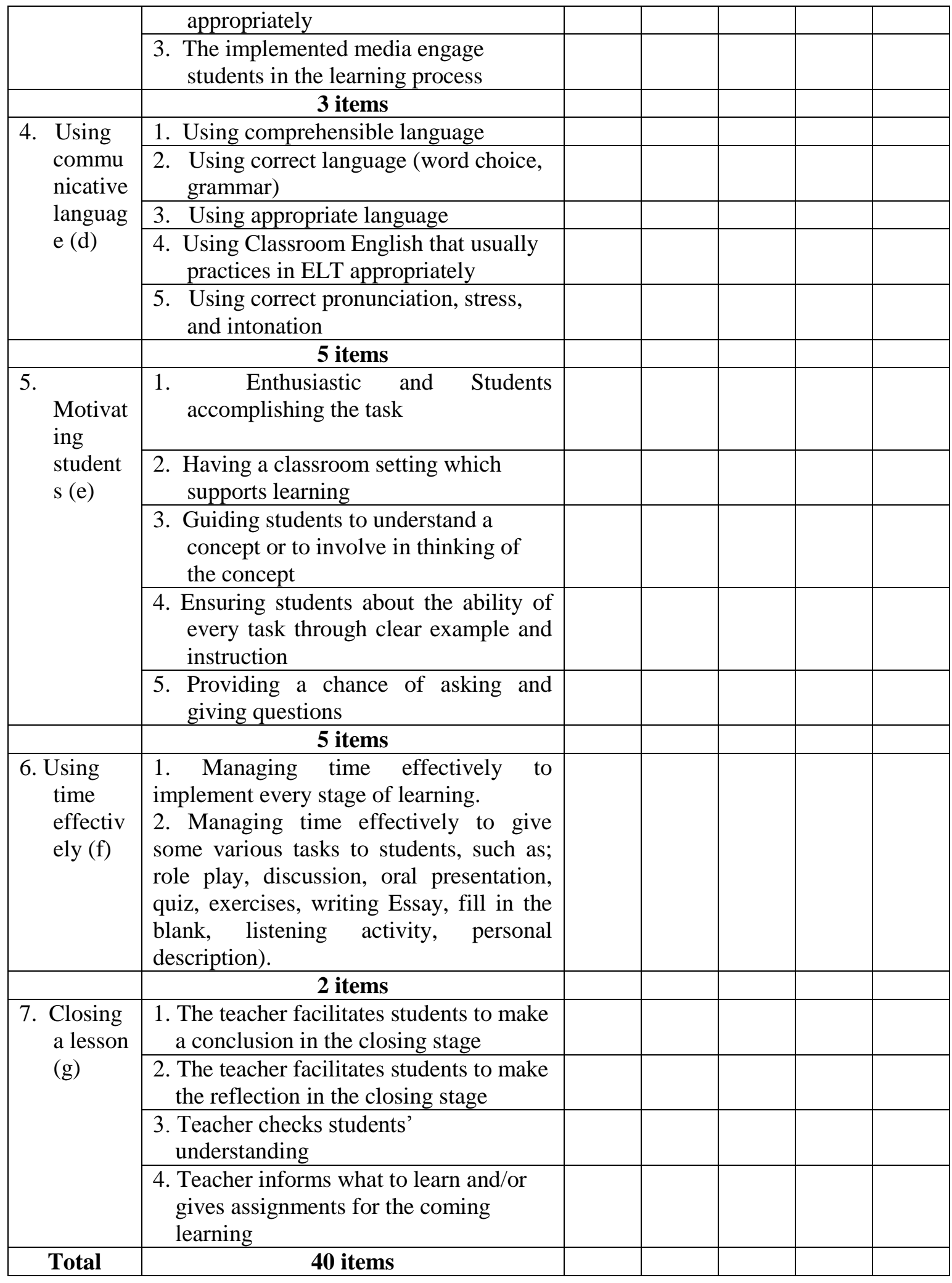

After conducting the pretest, the researcher got the highest score is 78 and the lowest score is 70 . From the data, the mean is 75.28 and the standard deviation is 
2.37206. They could not do the pretest maximally because some students still need much more guidance in applying teaching strategies. Actually, some of them were lack of self-confident and not ready to do teaching internship in some schools. They still used conventional and not interesting teaching strategy in their teaching practice. They also used some common vocabularies of Classroom English in giving instruction and explanation the material. They still had difficulty how to explore some task and activities for students. Based on that reasons, the researchers gave them the treatments how the implementation of TBLT.

Table 2

The Frequency Distribution of the Teaching Practice of Performance Test (Pre Test) before being taught by using TBLT

\begin{tabular}{|l|l|c|c|}
\hline No & Score & Frequency (F) & Percentage (\%) \\
\hline 1 & $75-78$ & 18 & 72 \\
\hline 2 & $71-74$ & 4 & 16 \\
\hline 3 & $67-70$ & 3 & 12 \\
\hline & & 25 & 100 \\
\hline
\end{tabular}

2. The Teaching Practice of the pre-service English teacher in the academic year 2015/2016 after being taught by using TBLT

After conducting the pre-test of teaching performance and giving the treatment by using TBLT with the main material of Suggesting, Reminding, and Advising Someone with "Should" for Senior High School, the post-test was conducted by the researcher to the pre-service English teacher in order to know their teaching performance after being taught by using TBLT. The researcher got that the result of the post-test is higher than the pre-test. The highest score is 86.36 and the lowest score is 77.

From the data, the mean of teaching performance after being taught by using TBLT is 81.36 and the standard deviation is 2.360791 . It is higher than before being taught by using TBLT. The mean after is 81.36 and before is 75.28 . They have more improvement in doing their post-test after being taught by using TBLT twice (treatment) in their class. The result can be categorized as a good criterion.

Table 3

Summary of the Teaching Practice before and after being taught by using TBLT

\begin{tabular}{|c|l|c|c|c|}
\hline .No & \multicolumn{1}{|c|}{ Research Result } & N & Mean & SD \\
\hline 1. & $\begin{array}{l}\text { The Teaching Practice of the pre- } \\
\text { service English teacher in the } \\
\text { academic year 2015/2016 before } \\
\text { being taught by using TBLT }\end{array}$ & 25 & 75.28 & 2.37206 \\
& $\begin{array}{l}\text { The Teaching Practice of the pre- } \\
\text { service English teacher in the }\end{array}$ & 81.36 & 2.36079 \\
\hline
\end{tabular}




\begin{tabular}{|l|l|l|l|l|}
\hline & $\begin{array}{l}\text { academic year 2015/2016 before } \\
\text { being taught by using TBLT }\end{array}$ & & & \\
\hline
\end{tabular}

The teaching practice of pre-service English teacher before and after being taught by using TBLT is different. According to the mean of both tests, the result of post-test is higher than pretest. It happened after the researcher gave the students twice treatment using beneficial teaching strategy of TBLT in solving their problems on teaching practice.

TBLT strategy contributes to the development of the teaching practice of the pre-service English teacher. Four procedures helped students to solve their problems. They are preparation, introduction, pre-task, during task and post-task. By giving them some interesting task and various activities as the part of preparation successfully made them easier to catch the idea for particularly on teaching practice. Group work in doing some task given gave them the opportunity to complete the information and increase their understanding. It also helped them to improve their self-confidence psychologically. Then, the problems undergone by students before being taught by using TBLT were gone.

The researcher implemented TBLT for the treatment in the class through some steps as follows:

1. The Learning Outcomes

a. Students are able to analyse the social function, the structure of the text, and linguistic elements on Suggesting expression, Reminding, and Advising Someone, and

b. Students are able to differentiate, the use, and the expression of Suggesting, Reminding, and Advising Someone with "Should" with respect to the social functions, the structure of the text, and the correct linguistic elements based on the context.

2. The Learning Materials

a. Pictures and Dialogue

\section{dialog 1}

Ferry: Hey, wake up! Let's have lunch.

ditto : I'm so sleepy.

Ferry : Why do you feel sleepy?

Dito: I watched a movie until one o'clock.

Ferry: You should have enough sleep so that you are not sleepy at the class.

Dito:What should I do? I'm really sleepy.

Ferry:We still have a class. You should wash your face.

Dito:You're right. I should have lunch, too.

Ferry:You do not have to go to the canteen. I have some slices of bread. I will share them with you.

Dito:Thank you. I'll wash my face first.

\section{dialogue 2}


Rani: What are you doing here? You should be going home.

Nisa:I'm waiting for my friends. We will go shopping.

Rani: But you should be changing your uniform.

Nisa:You're right. I bring a T-shirt. I will change it later.

Rani:I'll leave you here. I should be studying for the quiz tomorrow.

Nisa:A quiz? What quiz?

Rani:Math quiz. You should be studying for it. You will get a bad score again.

Nisa:All right. I'll cancel my appointment.

\section{dialogue 3}

Vonny: Why do you look so bad?

Seto: My laptop is broken.

Vonny: How come?

Seto:I should have gone home after the rain yesterday. I should have brought my raincoat. My bag was wet and my laptop was wet, too.

Vonny: you should have been careful when you brought your laptop to school.

Seto: You're right.

Vonny:You must bring your laptop to the service center. Perhaps it can be repaired.

Seto:Yes. I will go there after school.

\section{b. Obligation and Advice}

An obligation is something that you must do because of the law, promise, rules, etc.

An advice is an opinion that someone offers you about what you should do or how you should act in a particular situation.

Modal verbs usually used have to, must, and should.

c. Social Function
a. To give suggestion
b. To give advice
c. To warn someone
d. To obey the rule

d. Structure

Subject + Modal Verbs (have to / must / should) + Verb base

\section{Expressing Obligation}

a. Starting (Stating the problem)

b. Responding (giving advice)

Asking for advice

- What do you think I should do?

- What should I do?

- What do you suggest?

- What do you advise me to do?

- If you were me what would you do?

- What ought I to do?

- Do you think that I should ...?

Giving advice 
- If I were you I would / would not ....

- If I were in your shoes / position I would ...

- You had better / you'd better .....

- You should ...

- Your only option is to ....

- Why do not you ....?

- Have you thought about ....?

- Have you tried ...?

\begin{tabular}{|l|l|}
\hline \multicolumn{1}{|c|}{ Asking for advice } & \multicolumn{1}{c|}{ Giving advice about something } \\
\hline What should I do? & You should talk to them calmly. \\
\hline $\begin{array}{l}\text { Do you think we should } \\
\text { talk to them? }\end{array}$ & $\begin{array}{l}\text { Yes. I think you should talk to them } \\
\text { right now. }\end{array}$ \\
\hline What do you think? & $\begin{array}{l}\text { I think you should apologize to } \\
\text { them. }\end{array}$ \\
\hline
\end{tabular}

e. Advice, Opinion, and Correction

\begin{tabular}{|c|c|}
\hline $\begin{array}{l}\text { - You should have breakfast before } \\
\text { you go to school. }\end{array}$ & $\begin{array}{l}\text { - You should regularly to gain your } \\
\text { weight. }\end{array}$ \\
\hline $\begin{array}{l}\text { - Do not put your bicycle here. It } \\
\text { should be at the parking lot. }\end{array}$ & $\begin{array}{l}\text { - Do not sit on that chair. It should be } \\
\text { for the teacher. }\end{array}$ \\
\hline $\begin{array}{l}\text { - I think you should tell the teacher } \\
\text { about this problem. }\end{array}$ & - I think they should join the course. \\
\hline $\begin{array}{l}\text { - The children bring the tennis ball. } \\
\text { They should bring a soccer ball. }\end{array}$ & $\begin{array}{l}\text { - You should go to the library to get } \\
\text { the reference. }\end{array}$ \\
\hline $\begin{array}{l}\text { - I think we should finish our } \\
\text { homework as soon as possible. }\end{array}$ & $\begin{array}{l}\text { I do not think we should Participate } \\
\text { in the debate contest. }\end{array}$ \\
\hline
\end{tabular}

\section{f. The Use of "Should" for Obligation}

\begin{tabular}{|c|l|l|}
\hline $\begin{array}{l}\text { Should }+ \\
\text { Simple })\end{array}$ & $\begin{array}{l}\text { To give advice, suggestion, and } \\
\text { recommendation. } \\
\text { To express obligation, but it is } \\
\text { not as strong as "must". } \\
\text { Likely to express the situation in } \\
\text { the present. } \\
\text { To predict the situation in the } \\
\text { future. } \\
\text { To advise someone not to do } \\
\text { something Because it is bad or } \\
\text { wrong. }\end{array}$ & $\begin{array}{l}\text { You are too fat. You should go on } \\
\text { a diet. } \\
\text { You should not lie to your } \\
\text { Andi should be at home. Meet } \\
\text { him now! } \\
\text { You should be fine tomorrow. } \\
\text { You should not cheat on the } \\
\text { exam. }\end{array}$ \\
\hline $\begin{array}{l}\text { Should }+ \\
\text { continuous }\end{array}$ & $\begin{array}{l}\text { To express the idea that the subject } \\
\text { is not fulfilling Reviews their } \\
\text { obligation or is not acting sensibly. }\end{array}$ \\
\hline $\begin{array}{l}\text { Should }+ \\
\text { (Perfect) }\end{array}$ & $\begin{array}{l}\text { To express an action or idea that } \\
\text { you did not fulfill the obligation in } \\
\text { the past. }\end{array}$ & $\begin{array}{l}\text { You should be studying math now. } \\
\text { Tomorrow we will have a quiz. }\end{array}$ \\
\hline
\end{tabular}

3. The Learning Method

Approach: Scientific Approach 
Teaching Strategy: TBLT (Task-Based Language Teaching)

Task / Activity: Discovery Learning, role play, group discussions, Matching Game

\section{Learning Activities}

\begin{tabular}{|c|c|c|}
\hline Activity & Learning Activities & Time \\
\hline & & Minute \\
\hline Preliminary & $\begin{array}{l}\text { 1. Students respond to greetings from teachers. } \\
\text { 2. Student attendance is checked by the teacher. } \\
\text { 3. Physical and psychological students are prepared by the } \\
\text { teacher. } \\
\text { 4. Students are motivated to learn (teachers using Brain } \\
\text { Gym). } \\
\text { 5. Students answer questions about the material that has } \\
\text { been studied and related to the material to be studied. } \\
\text { 6. Teachers deliver power point slides to brainstorm. } \\
\text { 7. Students know the basic learning objectives or } \\
\text { competencies to be achieved. }\end{array}$ & $\begin{array}{c}5^{\prime} \\
\text { (PPK: } \\
\text { Integrity) }\end{array}$ \\
\hline
\end{tabular}




\begin{tabular}{|c|c|c|}
\hline Core/Main & $\begin{array}{l}\text { Observing } \\
\text { 1. Students form three groups using counting models and } \\
\text { joining the same number. } \\
\text { 2. The teacher distributes three dialogue and each group } \\
\text { will have one dialogue for discussing. } \\
\text { 3. Each group renamed themselves. } \\
\text { 4. Each group discussions; } \\
\checkmark \text { Mention the social function of the dialogue they } \\
\text { can. } \\
\checkmark \text { Jot difficult vocabulary that they find in the dialog. } \\
\text { 5. Teachers and students discuss the results of the } \\
\text { discussion along. } \\
\text { 6. Students are given the opportunity to ask the things they } \\
\text { have not understood with regard to the material. } \\
\text { Example: } \\
\text { 1. What is the purpose of dialogue Suggesting, } \\
\text { Reminding, and Advising Someone with "Should"? } \\
\text { 2. When do we use the expression? } \\
\text { 7. Students form a new group. } \\
\text { Steps: } \\
\text { - Participants in groups consist of 3-4 people by } \\
\text { Counting. } \\
\text { - Teachers provide practice in the form of images to be } \\
\text { discussed about expressions Suggesting, Reminding, } \\
\text { and Advising Someone with "Should" is appropriate. } \\
\text { - Groups that have developed should provide an } \\
\text { assessment of the advancing group. } \\
\text { 8. Teachers and students make corrections along. } \\
\text { 9. Students compare the expression used in each image. } \\
\text { 10. Students Individually draw up a dialogue about } \\
\text { Suggesting, Reminding, and Advising Someone with } \\
\text { "Should". } \\
\text { 11. Students answer questions based on the dialogue that } \\
\text { has been prepared. } \\
\text { 12. Teachers and students make corrections together. } \\
\text { anding }\end{array}$ & $\begin{array}{l}4 \mathrm{C} / \text { Creative } \\
4 \mathrm{C} \text { new } \\
\text { communicates } \\
\text { and critical } \\
\text { thinking } \\
5^{\prime}\end{array}$ \\
\hline Closing & $\begin{array}{l}\text { 1. Students and teachers reflect on their learning activities } \\
\text { and benefits. } \\
\text { 2. Students and teachers provide feedback on the process } \\
\text { and learning outcomes. } \\
\text { 3. Students pay attention to the information about the plan } \\
\text { learning activities for the next meeting. } \\
\text { 4. Students and teachers prayed for an end to the lesson. }\end{array}$ & $\begin{array}{c}5^{\prime} \\
\text { 4C / Critical } \\
\text { thinking }\end{array}$ \\
\hline
\end{tabular}


Nadiah Ma'mun |155

\section{TASKS}

(Do in pairs)

$\begin{array}{ll}\text { Name } & \text { : } \\ \text { Class } & : \\ \text { Student Number } & :\end{array}$

Answer the following questions According to the dialogue and the text!

Bedu: I would like to ask you how to solve my problem.

Motivator: What's your problem?

Bedu: I can't concentrate all the time. I can't study because have short concentration.

Motivator: You should relax. Use your leisure time as well as possible. You shouldn't do something too hard. It's not good for your mind. Just relax. Do something based on your strength.

Bedu: Thanks a lot.

1. What happens to Bedu?

2. What is the social function of the above dialog?

3. Mention the expression of giving advice found in the dialog!

Dear Anita,

I know that you are embarrassed to gather with us because you are very fat now. I'm sorry to hear that. But, can I give you some suggestions? I had ever been a fat girl for three years, but I can be a slim girl now. It was because of some efforts. Anita, I think you should eat less now. You should reduce to consume sugar. You should do exercise in the morning. You can run or jog around your house. Perhaps, you can go to the nearest gym. Don't limit your social interaction because of your body. You know that there are many fat women who are popular. They are confident with their body. However, if you want to lose your weight, you should do my suggestions. You should do it regularly. Well, let me know if you can lose your weight.

Best regards,

Anna

4. What is the purpose of the letter above? 
5. What happens to Anita?

6. What does the writer want Anita to do?

\section{Complete the following dialog with the suitable expressions!}

A. Man: Hi! You look so gloomy today, what's the matter?

Woman: Hello! I'm OK, buddy.

Man: 7) ............................................. Am I your best friend?

Woman: Yeah, but. Ok, I will tell you.

Man: Sure. C'mon!

B. Malika: George! Would you mind to turn your radio off?

George: My pleasure. I'm sorry for it.

Malika: 8)........................................... Tomorrow you will have English Quiz, right?

George: Oh God! I almost forget. Thanks by the way for reminding me, sister!

C. Man: Did you know about John?

Woman: I didn't know, what's going on?

Man: He won the national badminton championship last night.

Woman: Really? 9).

When He passed my house last

night too. I met him also just now.
a. I should have congratulated him.
b. You should tell me.
c. You should be studying now.

Match the situations below with the responses!

10. (.....) The class is truly dirty now.

11. (.....) I have no best friends because I'm a quiet person.

12. (.....) I need a dictionary, but it's too expensive.

a. You should be friendly to others.

b. We should be cleaning our class now.

c. You should have saved much money to buy it.

\section{Answer the following questions according to the above text!}

Dear Amanda,

I have a problem with my parents. They ask me to join a music course. You know I don't like music. I can't play any musical instruments. I can't sing, too. What should I do so that my parents understand me? 
Lidya

13. What is the writer's problem?

14. Imagine that you are Amanda! Write a replay to Libya's letter! Use "Should"!

3. The Significant Difference of the Teaching Practice of the pre-service English teacher in the academic year 2015/2016 before and after being taught by using TBLT

The researcher used t-test formula, the result of the significant difference of the teaching practice of the pre-service English teacher in the academic year 2015/2016 before and after being taught by using Task-Based Language Teaching is 8.90 was higher than t-table. The level of significance of $5 \%$ is 2.06 . It is gotten from the degree of freedom $(\mathrm{df})=\mathrm{N}-1=24$, so then $\mathrm{t}_{0}$ is higher than $\mathrm{t}$-table $\left(\mathrm{t}_{0}>\mathrm{t}\right.$-table $=$ $8.90>2.06$. So, it can be concluded that there is a significant difference in the teaching practice of the pre-service English teacher in the academic year 2015/2016 before and after being taught by using Task-Based Language Teaching.

Based on the result above, it can be concluded that using TBLT is good in solving the students' problems in teaching practice. It can decrease the students' difficulties and broaden their horizon to not only on the theory of teaching strategy but also the practice of the variation of the task. Using TBLT also increases their self-confidence. It proves the way their teaching was better than before. They implemented and developed TBLT with several of Task skillfully. Some students were enthusiastic and serious to learn and focus on some task given. TBLT is suitable strategy especially in a school that can be applied by pre-service English teachers. They explained the material clearly and gave several beneficial and interesting tasks to the students. Using TBLT, the pre-service English teachers used some beneficial task and varieties activities that make the class more life. A successful Task-Based lesson requires from pre-service English teachers: good preparation, creative atmosphere, and clear instruction. On the other hand, it requires from students: good preparation, participation, and using the target language.

Based on the findings, the result shows that it has a positive effect. It makes the pre-service English teachers implement TBLT as follows: the appropriateness of 
TBLT for all types of groups, It improves learners' interaction skills, It enhances learners' intrinsic motivation, It also supports collaborative learning. In addition, TBLT would fit a large class, that the only way to teach a large group was to give them some tasks, and most of the tasks require the group or pair work. There might be a little noise but that's how it goes. The pre-service English teachers should not worry too much about students producing perfect structures right away. It is best for the pre-service teachers not to overcorrect. It discussed that accuracy develops naturally.

\section{CONCLUSION}

The teaching practice of the pre-service English teacher in the academic year 2015/2016 before being taught by using TBLT, after conducting the pretest, the researcher got the highest score is 78 and the lowest score is 70 . From the data, the mean is 75.28 and the standard deviation is 2.37206 . Then, the post-test was conducted by the researcher to the pre-service English teacher, and the result is higher than the pre-test. It can be concluded that there has been a significant improvement after being taught by using TBLT twice (treatments) in their class. According to the t-test, the result of the significant difference of the teaching practice of the pre-service English teacher before and after being taught by using TBLT is 8.90 was higher than t-table. The level of significance of $5 \%$ is 2.06 . It is gotten from the degree of freedom $(\mathrm{df})=\mathrm{N}-1=24$, so then $\mathrm{t}_{0}$ is higher than $\mathrm{t}$-table $\left(\mathrm{t}_{0}>\mathrm{t}\right.$-table $=$ $8.90>2.06$. It means that there was a significant difference in the teaching practice of the pre-service English teacher in the academic year 2015/2016 before and after being taught by using TBLT.

\section{References}

Arikunto, Suharsimi. (2010). Prosedur Penelitian: Suatu Pendekatan Praktik. Jakarta : Rineke Cipta.

Brown, H. D. (2007). Teaching by Principles: An Interactive Approach to Language Pedagogy. Sun Francisco: Longman.

Cohen, L., Manion, L. \& Morrison, K. (2005). Research Methods in Education $\left(^{\text {th }}\right.$ ed.). New York: Routledge Falmer.

Gürses, A., Bayrak, R., Yalçın, M., Açıkyıldız, M., \& Doğar, Ç. (2005). Investigation of Effectiveness of Microteaching at Practicum. Kastamonu Education Journal. 
Fatah Huda. (2016). An Investigation of English Teaching Strategies in Enhancing Students Vocabulary Implemented by a Pre-Service English Teacher", Journal of English and Education, No. 4, Vol. 2.

Harmer, J. (2003). The Practice of English Language Teaching. Longman. London.

Hughes, Glyn S. (2013). A Handbook of Classroom English. Oxford University Press.

Johnson, Keith (ed). (1993). Communication in the Classroom. Burnt Mill: Longman.

Kagan, S. (1994). Cooperative Learning. San Clemente: Resources for Teachers.

Karckay, A. T., and Sanli, S. (2009). The effect of microteaching application on the pre-service teachers" teacher competency levels. Procedia Social and Behavioral Sciences.

Kubukcu, F. (2010). Congruence and dissonance between micro-teaching and macro-teaching. Procedia Social and Behavioral.

Larsen, Diane. (2002). Techniques and Principles in Language Teaching. New York: Oxford University Press.

Najjari. (2014). Implementation of Task-Based Language Teaching in Iran: Theoretical and Practical Consideration. $6^{\text {th }}$ International Conference on Current Trends in ELT. Procedia-Social and Behavioral Sciences.

Nunan, David. (1992). Research Method in Language Teaching. Cambridge University Press.

Nunan, David. (2015). Teaching English to Speakers of Other Languages. Routledge.

Manggopa, Rolina Emmy. (2015). Peningkatan Kemampuan Berbicara Bahasa Inggris dengan Metode Task-Based Language Teaching (TBLT). Dissertation. Pendidikan Bahasa Inggris Universitas Negeri Jakarta.

Peker, M. (2009). Pre-service Mathematics Teacher Perspectives about the Expanded Microteaching Experiences. Journal of Turkish Educational Science, 7(2), 353-376. 
Richards, Jack c and Willy A Renandya. (2002). Methodology in Language Teaching. Cambridge University Press.

Saban, A and Coklar, A. Pre-Service Teachers' Opinions About the Micro-Teaching Method in Teaching Practise Classes. Tojet (the Turkish Online Journal of Educational Technology - April 2013, Vol 12 Issue 2.

Sarı, Y., Sakal, M., \& Deniz, S. (2005). The Effectiveness of Micro-teaching in Preschool Teacher Education. Gaziantep University Academic Information 2005 Conference, 112-113.

Şen, A.I. (2009). A Study of Effectiveness of Peer microteaching in a Teacher Education program. Eğitimve. Bilim-Education and Science,34(151), 165-174.

Şen, A.İ. (2010). Effect of Peer Teaching and Micro-Teaching on Teaching Skills of Pre- Service Physics.

Slavin, Robert E. (1995). Cooperative Learning: Theory, Research \& Practice. Second Edition. Center for Research on Effective Schooling for Disadvantaged Students. The Johns Hopkins University.

Suryani, Fitri. (2017). Enhancing EFL student teachers' teaching practice through microteaching lesson study. Asian Journal of Educational Research. Vol 5. No.2.

Richard, Jack C. "Developing Classroom Activities: From Theory to Practice”, http://www.professorjackrichards.com/articles/, retrieved Mei 21, 2017.

Richard, Jack C, and Rodgers. (2014). T. Approaches and Methods in Language Teaching.Third Edition. Cambridge University Press.

Sadiq Abdulwahed Ahmed Ismail. (2011). Microteaching Experiences in a Preservice English Teacher Education Program Student Teachers. Journal of Language Teaching and Research, Vol. 2, No. 5, pp. 1043-1051, September 2011 (C) ACADEMY PUBLISHER. United Arab Emirates University, United Arab Emirates.

Sugiyono. (2006). Metode Penelitian Kuantitatif Kualitatif dan $R \& D$. Bandung: Alfabeta. 
Syamsussin and Damaianti. (2011). Metode Penelitian Pendidikan Bahasa. Cetakan ke-4. Rosda . Bandung.

Willis, J.(1996). A Framework for Task-Based Learning. Harlow: Longman. 